geal atresia ${ }^{13}$ and renal agenesis and renal dysplasia with von Maeyer-RokitanskiKüster complex. ${ }^{14}$

As yet, there is no consistent detectable chromosomal or metabolic cause of the $3 \mathrm{C}$ syndrome, including the 22q11.2 deletion discussed here. In the 16 families known to have children with the $3 \mathrm{C}$ syndrome, four males and 14 females, two had two affected daughters, three are related, and five belong to a small, isolated part of Canada with its own dialect. The most likely aetiology, therefore, is autosomal recessive inheritance, as proposed in the first report of the syndrome. It would be prudent, however, to exclude a deletion in 22q11.2 before a definitive diagnosis of $3 \mathrm{C}$ syndrome is made owing to possible overlap of the variable clinical features.

JORGE M SARAIVA

Consulta de Genética, Hospital Pediátrico de Coimbra, Avenida Bissaya Barreto, 3000 Coimbra, Portugal

EUNICE MATOSO ISABEL MARQUES

Unidade de Citogenética e Diagnóstico Prénatal, Instituto de Biologia Médica, Faculdade de Medicina de Coimbra, Portugal

1 Butler MG, Mowrey P. Should the 3C (craniocerebellocardiac) syndrome be included in the spectrum of velocardiofacial syndrome and DiGeorge sequence? $\mathcal{F}$ Med Genet 1996;33:71920.

2 Saraiva JM, Gama E, Pires MM, Sequeira JF. First report of glaucoma as a feature of the 3C syndrome. Clin Dysmorphol 1995;4:156-60.

3 McKusick VA. Mendelian inheritance in man: catalogs of autosomal dominant, autosomal recessive and $X$-linked phenotypes. 11th ed. Baltimore: The Johns Hopkins University Press, 1994

4 Digilio MC, Marino B, Giannotti A, Mingarelli R, Dallapiccola B. Atrioventricular canal and 3C (cranio-cerebello-cardiac) syndrome. $A m \mathcal{F}$ Med Genet 1995;58:97-8.

5 Marles SL, Chodirker BN, Greenberg CR, Chudley AE. Evidence for Ritscher-Schinzel syndrome in Canadian native indians. $A m \mathcal{F}$ Med Genet 1995;56:343-50.

6 Wulfsberg EA, Leana-Cox J, Neri G. What's in a name? Chromosome 22q abnormalities and the DiGeorge, velocardiofacial, and conotrun$\mathrm{cal}$ anomalies face syndromes. Am $\mathcal{F}$ Med Genet 1996;65:317-19.

7 Lynch DR, McDonald-McGinn DM, Zackai $\mathrm{EH}$, et al. Cerebellar atrophy in a patient with velocardiofacial syndrome. $\mathcal{F}$ Med Genet 1995; 32:561-3.

8 Goldberg R, Motzkin B, Marion R, Scambler PJ, Shprintzen RJ. Velo-cardio-facial syndrome: a review of 120 patients. $A m \mathcal{F}$ Med Gyndrome: a review of 120

9 Wilson DI, Burn J, Scambler P, Goodship J. DiGeorge syndrome - part of CATCH 22. $\mathcal{F}$ Med Genet 1993;30:852-6.

10 Lauener R, Seger R, Jörg W, Hallé F, Aeppli R, Schinzel A. Immunodeficiency associated with Dandy-Walker-like malformation, congenital heart defect, and craniofacial abnormalities. Am $\mathcal{F}$ Med Genet 1989;33:280-1.

11 Devriendt K, van Thienen MN, Swillen A, Fryns JP. Cerebellar hypoplasia in a patient with velo-cardio-facial syndrome. Dev Med Child Neurol 1996;38:949-53.

12 Hoo JJ, Kreiter M, Halverson N, Perszyk A. 3C (cranio-cerebello-cardiac) syndrome - a recently delineated and easily recognizable congenital malformation syndrome. $\mathrm{Am} \mathcal{F} \mathrm{Med}$ Genet 1994;52:66-9.

13 Fokstuen S, Bottani A, Medeiros PFV, Antonarakis $\mathrm{SE}$, Stoll $\mathrm{C}$, Schinzel A. Laryngeal atresia type III (glotic web) with 22q11.2 microdeletion: report of three patients. $A m \mathcal{F}$ Med Genet 1997;70:130-3.

14 Devriendt K, Moerman P, van Schoubroeck D, Vandenberghe K, Fryns JP. Chromosome 22q11 deletion presenting as the Potter sequence. $\mathcal{F}$ Med Genet 1997;34:423-5.

\section{A mother with VCFS and unilateral dysplastic kidney and her fetus with multicystic dysplastic kidneys: additional evidence to support the association of renal malformations and VCFS}

Devriendt et al recently described in this journal a female fetus with Potter sequence caused by unilateral renal agenesis and contralateral multicystic renal dysplasia, who was retrospectively found to have a deletion in chromosome 22q11 following identification of the deletion in the father. The father presented with typical VCFS features but no urological anomalies. We describe a patien with a clinical diagnosis of VCFS and a unilateral dysplastic kidney but with negative high resolution cytogenetic and FISH studies, who had a female fetus with bilateral multicystic kidneys. This provides additional evidence to support the conclusion of Devriendt $e t$ al that in VCFS the renal malformation can dominate the clinical phenotype.

Our patient is a 24 year old female initially referred because of facial dysmorphology and developmental delay. She had a long nose and a long, thin face, a small chin, prominent incisors, a deep philtrum (fig 1), a high palate which had the appearance of a cleft, velopharyngeal insufficiency, and long, thin fingers and toes. She also had a repaired ASD, developmental and speech delay, depression, chemical dependency, and seizures. A rena ultrasound showed a unilateral multicystic dysplastic kidney. Karyotype analysis and FISH using a digoxigenin labelled probe localised to 22q11.2 (Oncor Inc, Gaithersburg, MD) were negative. Her first pregnancy was uncomplicated and she delivered a healthy male with no dysmorphic features. He had a normal renal ultrasound and at the age of 2 years is developmentally appropriate. During her second pregnancy, ultrasound examination of her female fetus at 19 weeks 4 days identified bilateral multicystic kidneys

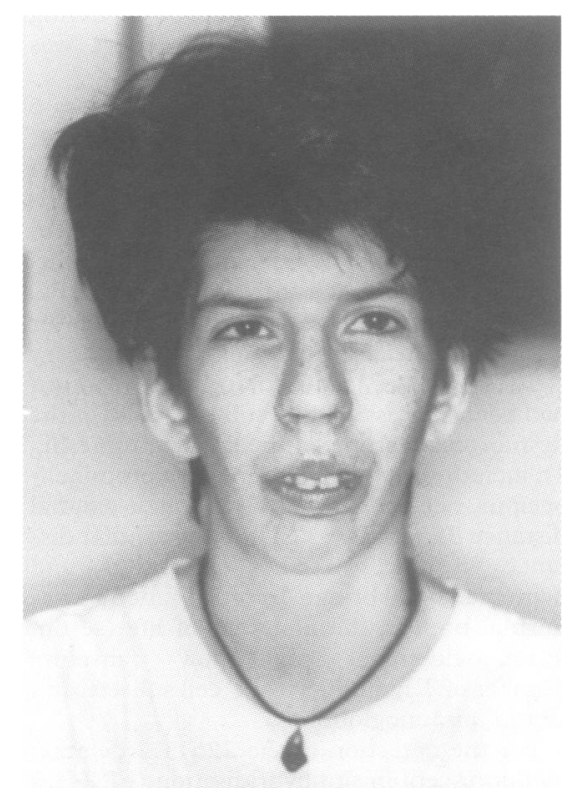

Figure 1 Patient with long nose, long, thin face, small chin, prominent incisors, and deep philtrum. and anhydramnios. The pregnancy was terminated and necropsy confirmed the presence of multicystic dysplastic kidneys, hypoplastic bladder, and low set ears. No other abnormalities were noted. Karyotype analysis was normal.

Of patients diagnosed clinically with VCFS, only 68 to $81 \%$ have a deletion of $22 q 11.2 .^{23}$ Several recent articles have noted the presence of nephrourological malformations as a component of VCFS syndrome. . $^{4}$ Of the 39 patients reported by Devriendt $e t$ $a$ t with $22 \mathrm{q} 11$ deletions, four had nephrourological malformations. Another patient with unilateral renal agenesis and dysmorphic features suggestive of DiGeorge sequence had a normal $\mathrm{G}$ banded karytoype. ${ }^{4}$ Driscoll et al reported a patient with a multicystic kidney and a normal karyotype; however, molecular studies showed the absence of a paternal 22q11 allele. Of 11 patients with DiGeorge syndrome reported by Palacios et al, ${ }^{7}$ one had a dysplastic right kidney and left ureterohydronephrosis and one had a right megaureter karyotype analysis was not performed on these two patients.

We concur with Devriendt et al that renal malformations associated with VCFS can lead to the Potter sequence and can dominate the clinical phenotype. These authors retrospectively investigated 10 additional cases of Potter sequence and no other patient with a $\operatorname{del}(22 q 11)$ was found. The possibility of performing FISH for 22q11.2 on all fetuses with Potter sequence, along with a thorough evaluation of both parents for physical features of VCFS, needs to be examined further.

PAULA M CZARNECK

DANIEL L VAN DYKE SUBODH VATS

GERALD L FELDMAN

Department of Medical Genetics, Henry Ford Hospital, 2799 W Grand Blvd, CFP-4, Detroit, Michigan 48202, USA

1 Devriendt K, Moerman P, Van Schoubroeck D, et al. Chromosome 22q11 deletion presenting as the Potter sequence. $f$ Med Genet 1997;34:423-5.

2 Driscoll DA, Salvin J, Sellinger B, et al. Prevalence of 22q11 microdeletions in $\mathrm{Di}$ George and velocardiofacial syndromes: implications for genetic counselling and prenatal diagnosis. F Med Genet 1993;30:813-17.

3 Lindsay EA, Greenberg F, Schaffer LG, et al Velo-cardio-facial syndrome: frequency and extent of 22q11 deletions. Am 7 Med Genet 1995;56:191-7.

4 Baldellou A, Bone J, Tamparillas M, et al. Congenital hypoparathyroidism, ocular colobomata, unilateral renal agenesis and dysmorphic features. Genet Couns 1991;2:245-7.

5 Devriendt K, Swillen A, Fryns JP, et al. Renal and urological tract malformations caused by a nd urological tract malformations caused by 22q11 deleti 9 Med Genet 1996,33.349.

6 Driscoll DA, Budarf ML, Emanuel BS. A genetic etiology for DiGeorge syndrome: consistent deletions and microdeletions of $22 \mathrm{q} 11$. Am F Hum Genet 1992;50:924-33.

7 Palacios J, Gamallo C, Garcia M, Rodriquez JI Decrease in thyrocalcitonin-containing cells and analysis of other congenital anomalies in 11 patients with DiGeorge anomaly. $\mathrm{Am} \mathcal{F} \mathrm{Med}$ Genet 1993;46:641-6.

\section{New overgrowth syndrome and FGFR3 dosage effect}

The 4p16 chromosome band is the object of intense scrutiny because the region is known to be genetically dense, containing many genes responsible for well known disorders such as the HD gene, ${ }^{2}$ FGFR $3,{ }^{3}$ and the Wolf-Hirschhorn critical region. ${ }^{4}$ More recently, the question has been raised whether 
the Pitt-Rogers-Danks syndrome may be caused by a deletion in the same region. ${ }^{5}$

In a recent issue of the fournal of Medical Genetics, Partington et al ${ }^{\beta}$ reported on a number of patients with deletions or duplications of $4 \mathrm{p} 16.3$, adding new information potentially useful for characterising this segment of the human genome.

However, in reading their article "Translocations involving $4 \mathrm{p} 16.3$ in three families: deletion causing Pitt-Rogers-Danks syndrome and duplication resulting in a new overgrowth syndrome", we have serious concerns about (1) their definition of a new overgrowth syndrome and, more importantly, (2) their idea that a triple dose of FGFR3 results in physical overgrowth.

First, we have rearranged the data from their table 2 to show that overgrowth is not really a prominent manifestation of duplication involving FGFR3 (table 1). For both height and head circumference, fewer than half of the patients have values $\geqslant 90$ th centile; only with respect to weight do slightly more than half of the patients have values $\geqslant 90$ th centile. On the other hand, a good proportion of patients have values $\leqslant 50$ th centile and even $\leqslant 25$ th centile. Combining all three parameters $(n=76)$, at the extremes, $28 \%$ of patients have values $\geqslant 97$ th centile and $8 \%$ have values $\leqslant 3$ rd centile. Although some values for all three growth parameters are large and the trend appears to be in that direction, so many patients have middle and lower range values that overgrowth per se does not seem to us to be a particularly prominent manifestation of dup ( 4 p 16.3). In fact, when thinking of classical overgrowth syndromes, such as Beckwith-Wiedemann syndrome, Simpson-Golabi-Behmel syndrome, or Bannayan-Riley-Ruvalcaba syndrome with overgrowth frequently present at birth, ${ }^{9}$ it is difficult to think of $\operatorname{dup}(4 \mathrm{p} 16.3)$ as an overgrowth syndrome at all.

Secondly, the function of FGFR3 can be deduced from the Fgfr3 -/- knockout mouse, ${ }^{10}$ which is overgrown with excessively long femora and elongated vertebrae, resulting in a long tail. Thus, the normal function of FGFR3 is to regulate endochondral ossification by "putting the brakes on growth"

Evidence is accumulating that the known mutations on FGFRs are of the gain of function type. For example, Neilson and Friesel ${ }^{11}$ made mutations in mRNA and expressed them in Xenopus that corresponded to known human mutations on FGFR1 and FGFR2. Analysis of mutant receptor proteins expressed in Xenopus oocytes indicated that all but one had increased tyrosine kinase activity compared to their wild type counterparts. FGFR3 mutations for achondroplasia and thanatophoric dysplasia have also been shown to have greatly increased levels of phosphotyrosine..$^{12}$ Ligand independent constitutive signalling produced by these mutations results in premature maturation of bones of the skeleton and cranium. This type of activation depends on the particular mutation and its location on the receptor and appears to result from (1) aberrant disulphide bonded or hydrogen bonded FGFR dimers

Table 1 Rearranged data

\begin{tabular}{llllr}
\hline & & \multicolumn{3}{c}{ Centiles (\%) } \\
\cline { 3 - 5 } & No & $\geqslant 90$ & $\leqslant 50$ & $\leqslant 25$ \\
\hline Height & 31 & 32 & 29 & 26 \\
Weight & 23 & 52 & 35 & 22 \\
Head circumference & 22 & 41 & 32 & 9 \\
\hline
\end{tabular}

or (2) involvement in the activation loop of the kinase domain. ${ }^{14}$

Thus, the mutations for short limb skeletal dysplasias on FGFR3 (hypochondroplasia achondroplasia, and thanatophoric dysplasia) are gain of function mutations that "put the brakes on even more" to various degrees. Fgfr3 +/- heterozygous mice have been shown to be normal. ${ }^{10}$

In conclusion, the idea put forth by Partington et at that FGFR3 in single dose leads to growth failure and in triple dose to physical overgrowth is not tenable in view of current clinical and experimental evidence.

M MICHAEL COHEN JR

Department of Oral and Maxillofacial Pathology, Department of Pediatrics, Dalhousie University Halifax, Nova Scotia, Canada GIOVANNI NERI

Istituto di Genetica Medica, Università Cattolica, Rome, Italy

1 Estabrooks LI, Breg WR, Hayden MR, et al. Summary of the 1993 ASHG ancillary meeting
"Recent research on chromosome 4p syn"Recent research on chromosome 4p syndromes and

2 John RM, Robbins CA, Myers RM. Identification of genes within CpG-enriched DNA from human chromosome 4p16.3. Hum Mol Genet 1994;3:1611-16.

3 Thompson LM, Plummer S, Schalling M, et al. A gene encoding a fibroblast growth facto receptor isolated from the Huntington disease gene region of human chromosome 4 . Genomics 1991;11:1133-42.

4 Wright TJ, Ricke DO, Denison $\mathrm{K}$, et al. A transcript map of the newly defined $165 \mathrm{~kb}$ Wolf-Hirschhorn syndrome initial region. Hum Mol Genet 1987;6:317-24.

5 Clemens M, Martsolf JT, Rogers JG, MoweryRushton P, Surti U, McPherson E. PittRushton P, Surti U, McPherson E. Pitt-
Rogers-Danks syndrome: the result of a $4 p$ Rogers-Danks syndrome: the result of a $4 \mathrm{p}$
microdeletion. Am $7 \mathrm{Med}$ Genet 1996;66:95100 .

6 Donnai D. Editorial comment. Pitt-RogersDanks syndrome and Wolf-Hirschhorn syndrome. Am ₹ Med Genet 1996;66:101-3.

7 Zollino M, Bova R, Neri G. From Pitt-RogersDanks syndrome to Wolf-Hirschhorn syndrome. And back? Am $\mathcal{f}$ Med Genet 1996;66 113-15.

8 Partington MW, Fagan K, Soubjaki V, Turner G. Translocations involving $4 \mathrm{p} 16.3$ in three families: deletion causing the Pitt-RogersDanks syndrome and duplication resulting in a new overgrowth syndrome. $\mathcal{F}$ Med Genet 1997; 34:719-28.

9 Cohen MM Jr. A comprehensive and critical assessment of overgrowth and overgrowth syndromes. In: Harris H, Hirschhorn K, eds. dromes. In: Harris $\mathrm{H}$, Hirschhorn $\mathrm{K}$, eds. Advances in human genetics. Vol 18. Chap 4.
New York: Plenum Press, 1989:181-303. Addendum, pp 373-6.

10 Deng C, Wynshaw-Boris A, Zhou F, Kuo A Leder P. Fibroblast growth factor receptor 3 is a negative regulator of bone growth. Cell 1996; 84:911-21.

11 Neilson KM, Ftiesel R. Ligand-independent activation of fibroblast growth factor receptors by point mutations in the extracellular, transmembrane, and kinase domains. $\mathcal{F}$ Biol Chem 1996;271:25049-57.

12 Naski MC, Wang $Q$, Xu J, Ornitz DM. Graded activation of fibroblast growth factor receptor 3 by mutations causing by mutations causing achondroplasia and 233-7.

13 Webster MK, Donoghue DJ. Constitutive activation of fibroblast growth factor receptor 3 by vation of fibroblast growth factor receptor 3 by the transmembrane domain point mutation found

14 Webster MK, Donoghue D. FGFR activation in skeletal disorders: too much of a good thing. Trends Genet 1997;13:178-82.

This letter was shown to Dr Partington et al, who reply as follows.

Thank you for the opportunity of seeing the comments of Cohen and Neri on our recent paper. We were mildly surprised at their confidence not only in dismissing the possibility of a dosage effect of FGFR3 on growth, but also in asserting that all the short stature syndromes associated with mutations in this gene are explained by loss of gain of function. We believe the jury is still out and all will be revealed in good time.

However, we must protest at Cohen and Neri's attempt to extinguish our overgrowth syndrome by the rather cavalier manipulation of the growth data presented in table 2 of our paper. They have chosen to ignore two explicit points stated in the text: first that II. 12 in family 1 is a special case because of severe disease (empyema), which probably limited growth in childhood and, second, that overgrowth "became more obvious in late adolescence and early adult life".

What Cohen and Neri have done is to take our mixed longitudinal and cross sectional growth data, translate it all into cross sectional data and, neglecting age, treat these measurements in the same way. This does dilute the overgrowth patterns observed. However, if one omits the data on II.12 for the reasons stated and takes the measurements at the oldest age of the 10 remaining subjects (all over the age of 15 years), then all the heights are at or above the 75 th centile and five of them are above the 90th centile. In the same way, the head circumferences are all at or above the 50th centile with five above the 97 th centile. This tells quite a different story from table 1 presented in Cohen and Neri's letter.

Some confirmation of this late growth pattern emerges from the heights recorded on II.11 and II.12 from family 1 . Thus, between the ages of 18 and 28 years 5 months, II. 11 grew $15 \mathrm{~cm}$ and between 17 years 5 months and 28 years II. 12 grew $26 \mathrm{~cm}$. Such growth increments are commonplace between the ages of 12 and 16 years, but are quite abnormal after the age of 17 years.

Physical measurements do not convey the whole picture. Clinically, those with overgrowth appear to be big people with large body frames, prominent supraorbital ridges, heavy facial features, and big hands and feet. Some, but not all, of these features are shown in the illustrations in our article.

Lastly, your readers may be interested to know that since our paper was published we have managed to meet III. 8 in family 1 again and, on this occasion, were able to make some measurements and take a blood sample. At the age of 33 , III.8 is a big woman with a heavy body frame and rather coarse or heavy facial features of which she is self-conscious and will not allow herself to be photographed. Her height is $180 \mathrm{~cm}$, head circumference 60 $\mathrm{cm}$, and hand length is $20.5 \mathrm{~cm}$. She has mild intellectual handicap and a duplication of $4 \mathrm{p} 16.3$.

\section{MICHAEL PARTINGTON GILLIAN TURNER \\ Hunter Genetics, PO Box 84, Waratah, New South Wales 2298, Australia}

\section{Robinow syndrome}

I would like to comment on the paper by Sabry et $a l^{1}$ in the September issue of the fournal of Medical Genetics. In it, they describe three patients they diagnosed as having Robinow syndrome in conjunction with a number of unusual abnormalities.

When looking at the photographs of their patients, I doubt whether the diagnosis of Robinow syndrome is correct, especially in the first patient. She has a number of facial characteristics that are indeed seen in Robinow syndrome, such as hypertelorism and 